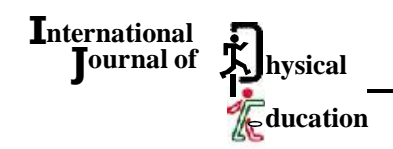

DOI : 10.15740/HAS/IJPE/7.2/71-74 e ISSN-0976-7924 | Visit us - www.researchjournal.co.in

Research Paper

Volume 7 | Issue 2 | October, 2014 | 71-74

\title{
Relationship of breath holding with vital capacity among swimmers
}

\section{VIJENDER RATHI}

Received : 06.09.2014; Revised : 11.09.2014; Accepted : 24.09.2014

Author for correspondence : VIJENDER RATHI

Department of Physical Education, Noida College of Physical Education, Dhoom Manikpur, Dadri, G.B. NAGAR (U.P.) INDIA

\section{- ABSTRACT}

The purpose of this study was to find out the relationship of Breath holding capacity with Vital capacity among swimmers. For the purpose of this investigation 20 male and female swimmers of Lakshmibai National University Physical Education, Gwalior were selected for the study their age ranging between 18-24 years. The data of Breath holding and Lung capacities of 20 male and female swimmers were obtained by administrating the standardised test and measurement procedures. The statistical technique used was Pearson's product movement correlation to find out the relationship of Breath holding and vital capacities among swimmers. The significance of " $\mathrm{r}$ " correlation co-efficient was seen with 8 degree of freedom and at 0.05 level of confidence among swimmers.

- Key Words : Breath holding, Vital capacity, Swimmers

- How to cite this paper : Rathi, Vijender (2014). Relationship of breath holding with vital capacity among swimmers. Internat. J. Phy. Edu., 7 (2) : 71-74. 